ARTICLE

Received 21 Nov 2015 | Accepted 4 Apr 2016 | Published 17 May $2016 \quad$ DOl: 10.1038/ncomms11500 OPEN

\title{
Decimetre-scale multicellular eukaryotes from the 1.56-billion-year-old Gaoyuzhuang Formation in North China
}

Shixing Zhu' ${ }^{1,2}$, Maoyan Zhu ${ }^{3}$, Andrew H. Knoll ${ }^{4}$, Zongjun Yinn ${ }^{3}$, Fangchen Zhao ${ }^{3}$, Shufen Sun ${ }^{1}$, Yuangao $\mathrm{Qu}^{5}$, Min $\mathrm{Shi}^{2} \&$ Huan Liu ${ }^{1}$

Fossils of macroscopic eukaryotes are rarely older than the Ediacaran Period (635-541 million years (Myr)), and their interpretation remains controversial. Here, we report the discovery of macroscopic fossils from the 1,560-Myr-old Gaoyuzhuang Formation, Yanshan area, North China, that exhibit both large size and regular morphology. Preserved as carbonaceous compressions, the Gaoyuzhuang fossils have statistically regular linear to lanceolate shapes up to $30 \mathrm{~cm}$ long and nearly $8 \mathrm{~cm}$ wide, suggesting that the Gaoyuzhuang fossils record benthic multicellular eukaryotes of unprecedentedly large size. Syngenetic fragments showing closely packed $\sim 10 \mu \mathrm{m}$ cells arranged in a thick sheet further reinforce the interpretation. Comparisons with living thalloid organisms suggest that these organisms were photosynthetic, although their phylogenetic placement within the Eukarya remains uncertain. The new fossils provide the strongest evidence yet that multicellular eukaryotes with decimetric dimensions and a regular developmental program populated the marine biosphere at least a billion years before the Cambrian Explosion.

\footnotetext{
${ }^{1}$ Tianjin Institute of Geology and Mineral Resources, China Geological Survey, Tianjin 300170, China. ${ }^{2}$ State Key Laboratory of Biogeology and Environmental Geology, China University of Geosciences, Wuhan 430074, China. ${ }^{3}$ State Key Laboratory of Palaeobiology and Stratigraphy, Nanjing Institute of Geology and Palaeontology, Chinese Academy of Sciences, Nanjing 210008, China. ${ }^{4}$ Department of Organismic and Evolutionary Biology, Harvard University, Cambridge, Massachusetts 02138, USA. ${ }^{5}$ Centre for Geobiology, University of Bergen, Bergen 5007, Norway. Correspondence and requests for materials should be addressed to M.Z. (email: myzhu@nigpas.ac.cn).
} 
U nambiguous fossils of macroscopic eukaryotes are widespread in Ediacaran sedimentary rocks ${ }^{1-4}$, and recently this record has been extended downward into intraglacial shales (ca. 636 Myr) of the terminal Cryogenian Nantuo Formation, South China ${ }^{5}$. With this in mind, the late Neoproterozoic Era has commonly been viewed as a time of transition from an earlier microbial biosphere to the world of conspicuous macroscopic organisms we know today ${ }^{6}$. Statistically, this view is correct, but reports of older macroscopic fossils have been published for years, including the Mesoproterozoic helicoid Grypania ${ }^{7,8}$, string-of-beads impressions named Horodyskia ${ }^{9,10}$ and scattered carbonaceous compressions of irregular or indeterminate shape ${ }^{11,12}$. Both the cellular structure and phylogenetic affinities of these fossils remain uncertain ${ }^{13,14}$. In particular, carbonaceous macrofossils up to $2 \mathrm{~cm}$ long, previously reported from upper Paleoproterozoic $(>1,625 \mathrm{Myr})$ shales in North China ${ }^{15,16}$, have irregular shapes and lack cellular structure, making it impossible to differentiate them from ripped-up and redeposited fragments of microbial mats ${ }^{13,17,18}$. Perhaps even more controversial are $\mathrm{cm}$-scale pyritic structures from 2.1-billion-year-old shales in Gabon ${ }^{19,20}$.

Here, we report an assemblage of large and unusually wellpreserved carbonaceous compressions from the lower Mesoproterozoic Gaoyuzhuang Formation in the Yanshan area, North China. Altogether, their large (decimetre-scale) size and regular, strongly elongate morphology differentiate these remains from contemporaneous or younger structures formed by the reworking of microbial mats. Rather, the Gaoyuzhang compressions closely resemble macroscopic eukaryotic organisms, especially benthic algae, observed today and in younger rocks. Phylogenetic placement of these remains is uncertain, but they indicate that simple macroscopic multicellularity evolved early in the eukaryotic domain.

\section{Results}

Fossil localities and geological setting. The Proterozoic succession in the Yanshan region (Fig. 1) consists of essentially undeformed sedimentary rocks about $10 \mathrm{~km}$ thick, dated by means of zircon U-Pb ages from tuffs, flows, sills and dykes ${ }^{21,22}$. Macrofossils were discovered at two localities in Qianxi and Kuancheng counties (Figs 1c and 2) within calcareous shales of the Gaoyuzhuang Formation ${ }^{22}$. The fossiliferous mudstones are rich in organic carbon (total organic carbon of $0.7-4.3 \%$; mean $=1.2 \%$; see (ref. 23 ) and are thought to represent distal turbidites or tempestites deposited near storm wave base. The fossiliferous shales lie below an ash bed dated by U-Pb zircon analysis at $1,560 \pm 5 \mathrm{Myr}$ and postdate $1,625 \pm 6.2 \mathrm{Myr}$ flows in the unconformably underlying Dahangyu Formation 24,25 (Figs 1d and 2).

Description and interpretation of carbonaceous compressions. The fossils are preserved as carbonaceous compressions within $\mathrm{mm}$ - to $\mathrm{cm}$-thick mudstone layers; they vary in size, orientation and degree of twisting or folding and, in general, appear to be allochthonous remains, deposited along with encompassing
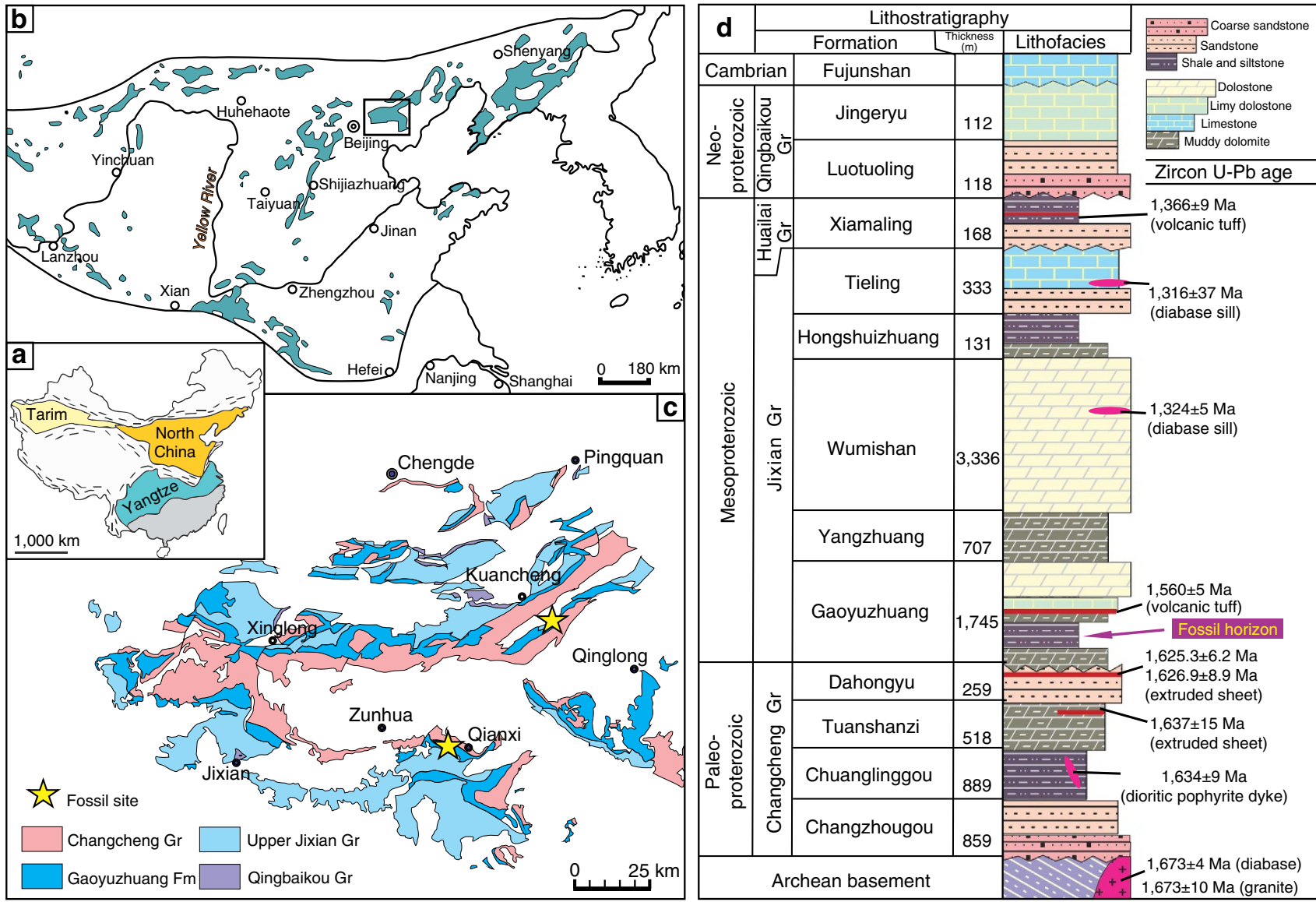

Figure 1 | Locality maps and stratigraphy. (a) Location of the North China, Yangtze and Tarim cratons. (b) Proterozoic outcrops within the North China craton-black box marks the Yanshan area. (c) Regional map of the Proterozoic outcrop within the Yanshan area, showing fossil localities. (d) Generalized Proterozoic stratigraphy in the Yanshan area (on the basis of the stratotype sections in Jixian), showing lithofacies, zircon U-Pb ages (on the basis of (refs 20,21,23,24) and references therein), and fossiliferous horizon. 
a

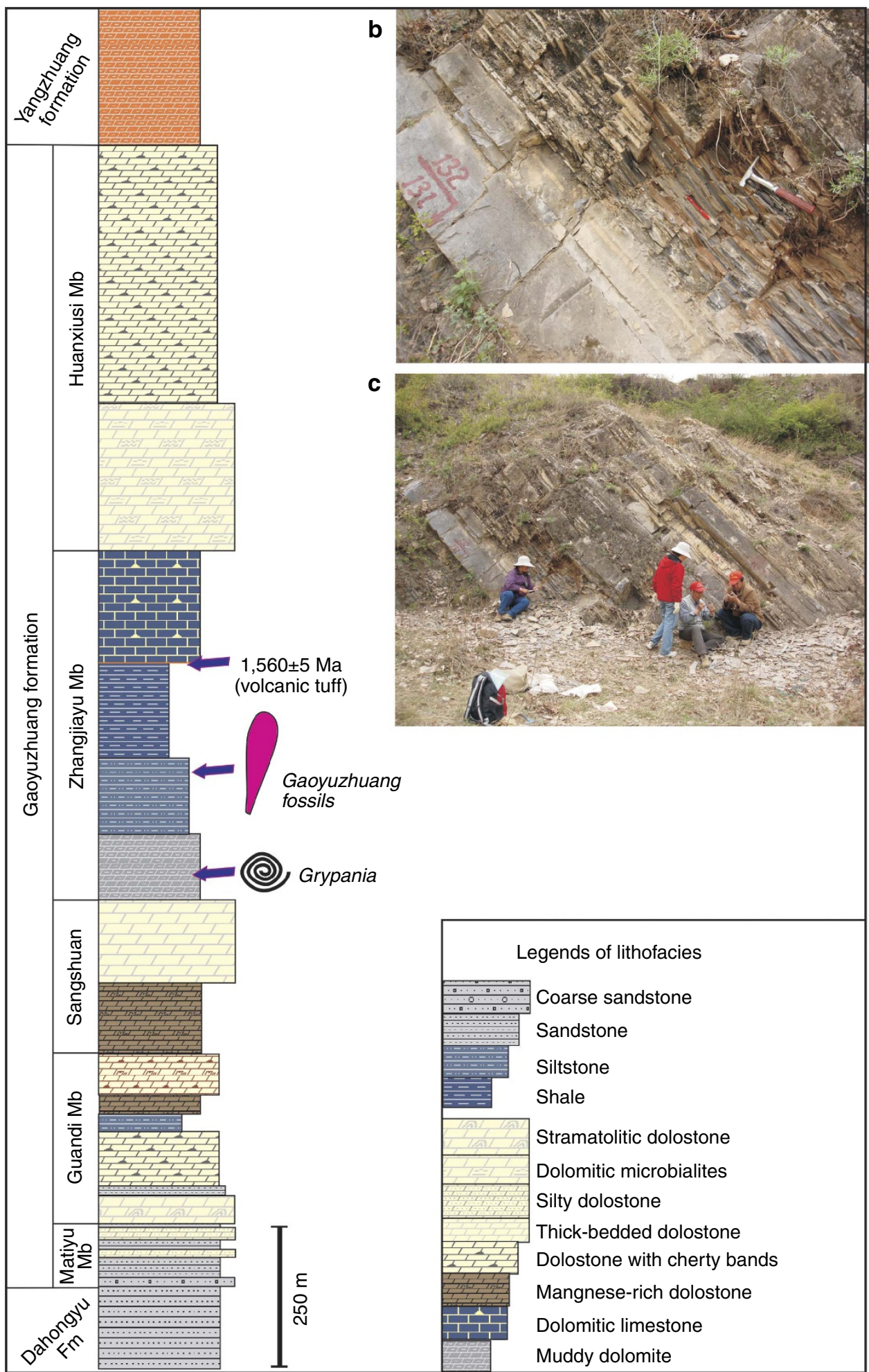

Figure 2 | The Gaoyuzhuang Formation in the Yanshan area. (a) Generalized stratigraphic log of the Gaoyuzhuang Formation in the Yanshan area, showing variation of lithofacies and fossil horizon. $(\mathbf{b}, \mathbf{c})$ Field photographs showing fossiliferous calcareous shales in the middle Gaoyuzhuang Formation near Yamenzi Village, Hebei.

muds transported over short distances (Fig. 3; Supplementary Figs 1,2). Small fragments with irregular shapes are common in the mudstone, but abundant, well-preserved compressions of large size and regular shape have been found in only a few horizons, particularly in the Qianxi area. We measured 167 individuals with a dimension greater than $15 \times 3 \mathrm{~mm}$ based on all the collected specimens (Supplementary Data 1 and Supplementary Table 1). In all, 53 individuals with regular shapes can be assigned to four morphotypes (Figs 3,4; Supplementary Figs 2,3): linear (elongate with parallel sides, truncated at both ends), cuneate (distinct taper on one end; other end truncated), oblong (rounded on one end) or tongue-shaped 

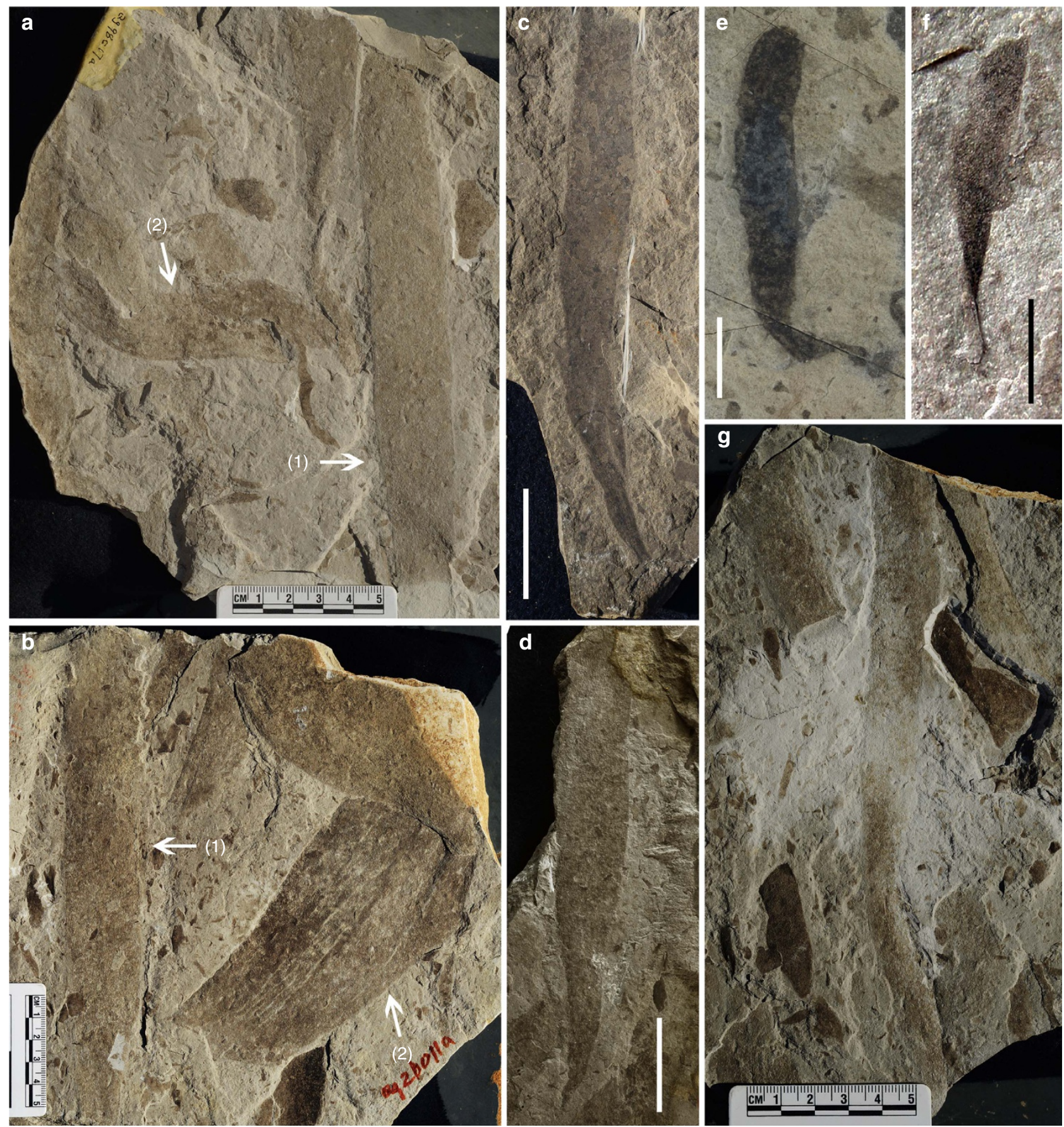

Figure 3 | Macroscopic fossils from the Gaoyuzhuang Formation. (a) Linear fossil without preservation of either end (a(1)) and fragment of tongueshaped fossil (a(2)), Qg98017. (b) Linear fossil without preservation of either end (b(1)) and tongue-shaped fossil with longitudinal striations (b(2)), Qg20011; (c,d) Cuneate fossils, 07kg1332 (c), Qg20017 (d). (e) Oblong fossil with possible holdfast, 07 kg1331. (f) Cuneate fossil preserved with differentiated holdfast, Qg98021; (g) linear fossil without preservation of either end. Scale bars, $5 \mathrm{~cm}$ (in a,b,g), $20 \mathrm{~mm}$ (in c), $40 \mathrm{~mm}$ (in d) and $5 \mathrm{~mm}$ (in e,f).

(round end, but without parallel sides). Unlike mat fragments, these compressions have sharp margins on at least two sides. Each shape class shows a more or less normal size frequency distribution (Fig. 5).

Cuneate fossils are up to $18 \mathrm{~cm}$ long with various divergence angles $\left(10-25^{\circ}\right)$ characterizing the tapering end and a ribbon-like (up to $4.2 \mathrm{~cm}$ wide) distal part with sharp and nearly parallel margins (Fig. 3c,d). No holdfast was preserved in large specimens, but a rod-like basal stipe can be seen in one small cuneate specimen (Fig. 3f). The linear fossils are up $22.9 \mathrm{~cm}$ long and $4.5 \mathrm{~cm}$ wide with ragged ends, suggesting they are fragments of larger individuals. The linear specimens (Fig. 3a(1),b(1),g) resemble the distal ends of cuneate compressions, and size frequency distributions for the two morphotypes overlap strongly (Fig. 5). Although slightly bent or twisted forms can be observed (Fig. 3g), most linear fossils are straight and have a smooth, slightly convex surface (Fig. $3 a(1), b(1))$, suggesting that the thallus was originally composed of mechanically strong organic materials.

Morphometric data suggest that the linear and cuneate remains are drawn from the same source population, an interpretation further supported by statistical data on tapering ratios for all 
Total number of individuals: 53

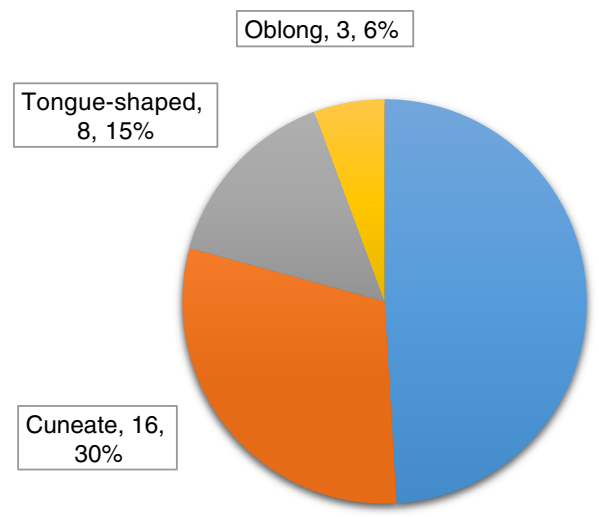

Linear, $26,49 \%$

Figure 4 | Relative abundance of morphotypes within the Gaoyuzhuang assemblage. Individuals (total $n=53$ ) with regular shapes consist of four morphotypes. Blue $=$ linear ( 26 individuals, $49 \%$ of total number); orange $=$ cuneate $(16$ individuals, $30 \%$ of total number); grey $=$ tongueshaped ( 8 individuals, $15 \%$ of total number); yellow = oblong ( 3 individuals, $6 \%$ of total number).

a

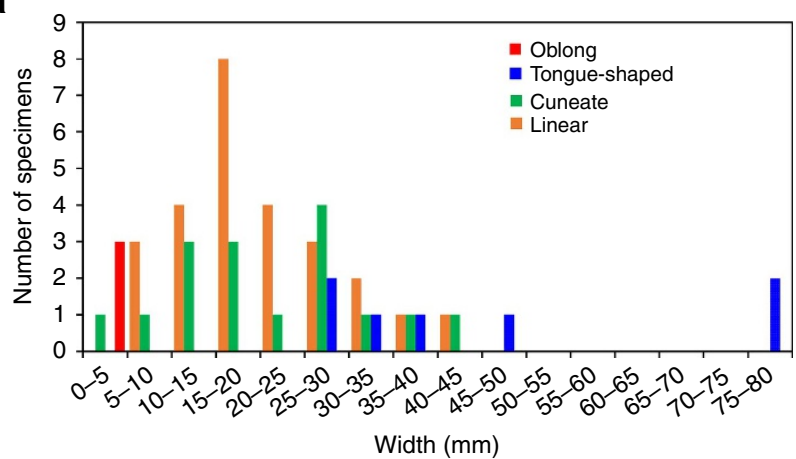

b

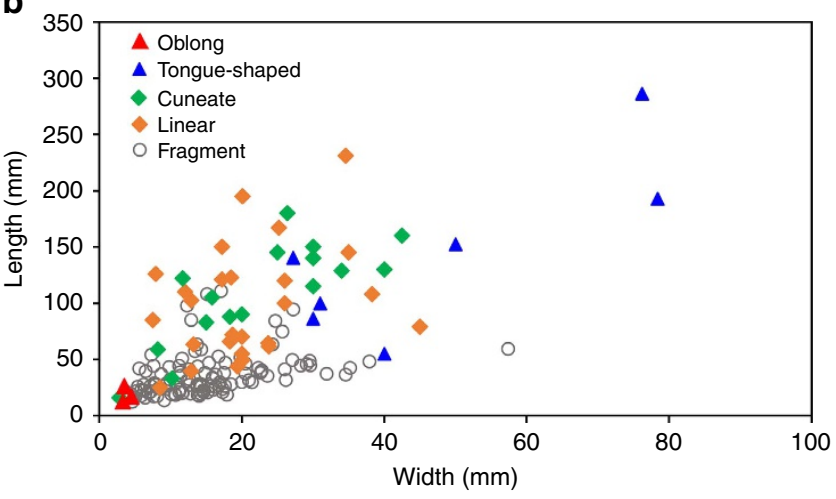

Figure 5 | Shape distribution of the Gaoyuzhuang macroscopic fossils.

(a) Histogram showing the size frequency distribution of maximum widths within and among morphotypes: oblong (red), tongue-shaped (blue), cuneate (green), and linear (orange). (b) Plot of length versus maximum width for all measured fossil individuals from the Gaoyuzhuang assemblage. Red triangle $=$ oblong, blue triangle $=$ tongue-shaped, green

diamond $=$ cuneate, orange diamond $=$ linear, and black circle $=$ fragments.

individuals of both forms (Fig. 6). If this inference is correct, the source thalli could have reached lengths of $>30 \mathrm{~cm}$ (Supplementary Fig. 3). Oblong fossils could also be drawn from this source, but one complete thallus (Fig. 3e) exhibits a narrow

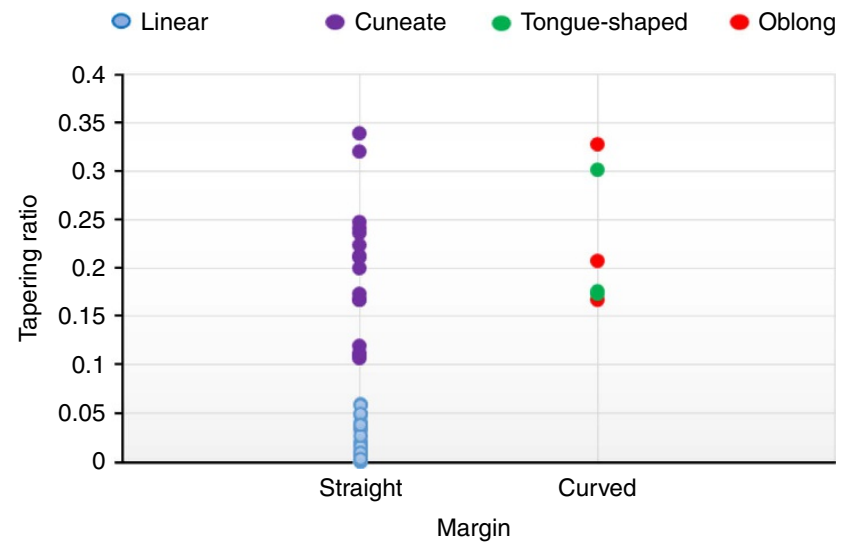

Figure 6 | Comparison of tapering ratios and overall shape among the morphotypes. Tapering ratios $\left(T=W_{\max }-W_{\min } / L^{\prime}\right.$; see the 'Methods' section) of cuneate and linear morphotypes with straight margins show in one line without overlap. Tapering ratios of tongue-shaped and oblong morphotypes with curved margins overlap each other.

ribbon-like base with a terminal spheroidal expansion that may represent a distinct holdfast (Supplementary Fig. 3).

Tongue-shaped remains are distinct in size as well as shape, suggesting that they record another distinctive thallus type (Figs $3 \mathrm{~b}(2)$ and 5; Supplementary Fig. 3). The tongue-shaped fossils are the largest remains in the assemblage (Figs $3 \mathrm{a}(2), \mathrm{b}(2)$ and 5), with dimensions up to $28.6 \mathrm{~cm}$ by $7.6 \mathrm{~cm}$ (Fig. $3 \mathrm{~b}(2)$ ). Blades clearly had a rounded distal end (Fig. $3 \mathrm{~b}(2)$ ), but the basal morphology remains unclear. Regular longitudinal striations run parallel to the long axis of the tongue-shaped fossils, providing further evidence of complex organization (Fig. 3b(2)). These broad fossils are commonly folded or otherwise deformed (Supplementary Fig. 1), suggesting a composition distinct from that of linear/conical thalli.

Morphometric analysis (Figs 4-6) further supports the hypothesis that Gaoyuzhuang carbonaceous compressions preserve at least two and possibly three populations of large macroscopic thalli (Supplementary Fig. 3) that grew according to simple but regular developmental programs, and rules out their interpretation as colonial prokaryotes or irregular mat fragments. The regular elongated shapes (and much larger size) of the Gaoyuzhuang fossils clearly differentiate them from the irregular carbonaceous compressions reported from the older Tuanshanzi Formation in the same area ${ }^{15}$. Moreover, the size and shape distribution of the Gaoyuzhuang compressions (Fig. 5) essentially rule out interpretation as ripped up and redeposited microbial mat fragments. The only plausible alterative is that the Gaoyuzhuang compressions represent decimetre-scale macroscopic, multicellular eukaryotes, and that is how we interpret them here.

Syngenetic multicellular fragments. The inference of organized multicellularity is reinforced by well-preserved cell sheets in organic fragments extracted from fossiliferous samples by acid maceration (Fig. 7). The fragments (up to $1 \mathrm{~mm}$ in diameter) consist of polyhedral cells $6-18 \mu \mathrm{m}$ in diameter $($ mean $=10 \mu \mathrm{m})$, closely packed to form a continuous surface. There is little evidence for cell files or other types of tissue organization. Neither is there evidence for cell differentiation within preserved sheets. The cellular fragments are translucent, with various optical densities under light microscopy, indicating they are made of thermally altered organic matter. This composition is 

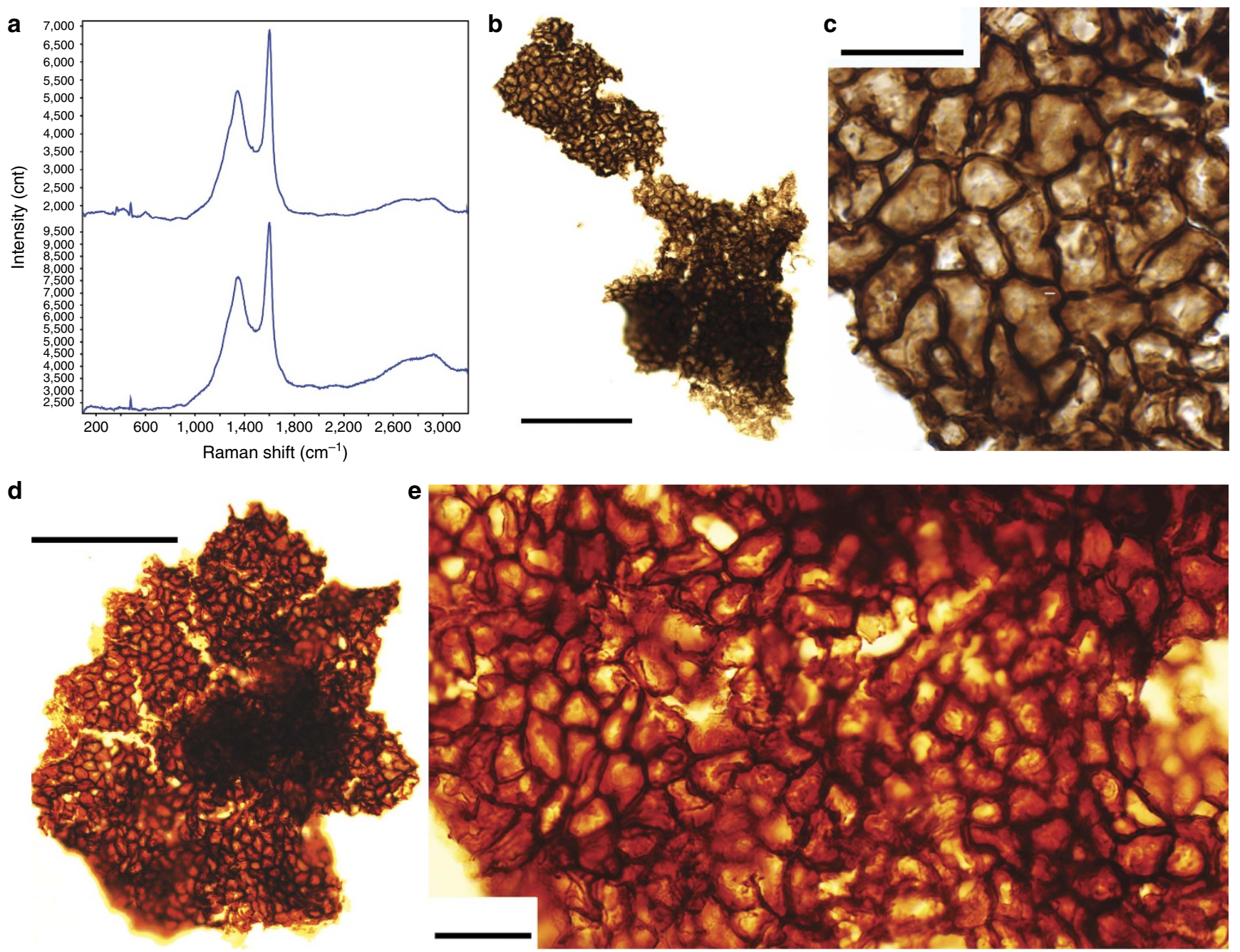

Figure 7 | Organic fragments showing cellular structure and Raman microspectroscopy. (a) First-order Raman spectrum of the carbonaceous organic extracted by acid maceration: fragments with cellular structure (top), fragments without cellular structure (bottom). (b,d) Organic fragments with preserved cellular structure. (c,e), Polygonal cells forming a multi-layered network, $\mathbf{c}$ shows a detail of $\mathbf{b}$, e shows a detail of $\mathbf{d}$. Scale bars, $100 \mu \mathrm{m}$ (in $\mathbf{b}, \mathbf{d}), 20 \mu \mathrm{m}$ (in $\mathbf{c}, \mathbf{e}$ ).

corroborated by Raman first-order spectra, which are dominated by $\mathrm{D}$ and $\mathrm{G}$ bands characteristic of disordered carbonaceous material (kerogen; Fig. 7a; Supplementary Fig. 4). Raman firstorder spectra of in situ macrofossils (see Supplementary Fig. 5) are similar, supporting the syngeneity of cellular remains within the host rock. The cellular fragments can easily be differentiated from the reticulate vesicles of contemporaneous acritarchs (for example, Dictyosphaera and Shuiyousphaeridium) in both size and ornamentation ${ }^{26-28}$. We cannot unambiguously demonstrate that the cell sheets originated within the thalli, but the absence of other microscopic fossils or other evident sources for these fragments, and indeed the absence of comparable cell sheets with dimensions $>1 \mathrm{~mm}$ in any known Mesoproterozoic deposit, makes attribution of the cell sheets to the macroscopic thalli reasonable. We emphasize that the interpretation of the thalli as macroscopic eukaryotes is strong regardless of how one evaluates the cell sheets.

\section{Discussion}

We conclude that the Gaoyuzhuang compressions record a modest diversity of macroscopic multicellular eukaryotic organisms that lived in shelf areas of early Mesoproterozoic oceans. Although large, the thalli are thin, which would have facilitated diffusion of nutrients and gases $^{20,29,30}$. The longitudinal striations on tongue-shaped fossils (Fig. 3b(2)), along with evidence for apical growth and differentiated holdfasts, provide circumstantial evidence for at least limited cell differentiation. On the basis of the comparisons with modern organisms, the thalli were most likely photosynthetic, although one can imagine a possible osmotrophic alternative. Molecular clocks differ in their estimates of when photosynthesis became established in the common ancestor of archaeplastid (glaucocytsophyte, red and green) algae. For example, clock estimates by Yoon et al. ${ }^{31}$, Parfrey et al. $^{32}$ and Eme et al. ${ }^{33}$ are consistent with the interpretation of Gaoyuzhuang fossils as archaeplastids, whereas reports by Douzery et al..$^{34}$, Berney and Pawlowsky ${ }^{35}$ and the ATPase- $\alpha$ calculations of Shih and Matzke ${ }^{36}$ are not. If archaeplastids, most molecular clocks would favour placement of the Gaoyuzhuang populations in stem groups rather than crown group red or green algae. Alternatively, the fossil could represent extinct eukaryotes that evolved simple multicellularity and photosynthesis independently of extant taxa.

Whatever their precise affinities, the Gaoyuzhuang fossils provide the most compelling evidence yet reported that by the beginning of the Mesoproterozoic Era, 1,600 Myr ago, eukaryotic organisms had evolved macroscopic form, multicellularity with limited cell differentiation, and (probably) photosynthesis. If so, their rarity as fossils in pre-Ediacaran $(>635 \mathrm{Myr})$ must reflect processes of preservation rather than simple biological absence. Continuing 
research promises new insights into marine ecosystems in the low oxygen world caricatured misleadingly as a 'boring billion' year interval of evolutionary as well as environmental stability $6,37,38$.

\section{Methods}

The fossil specimens for this study were collected from calcareous mudstone of the Zhangjiayu Member of the Gaoyuzhuang Formation at Doulingzi village, Qianxi and Yamenzi village, Kuancheng (Figs 1,2). Specimens are reposited at the Tianjing Institute of Geology and Mineral Resources, China Geological Survey. Collection numbers of illustrated specimens are 07kg1332, 07kg1331, Qg98017, Qg98021, Qg98024, Qg20011 and Qg20017. Morphometric data are provided in Supplementary Data 1 and Supplementary Table 1, including tapering ratio $=\mathrm{W}_{\max }-\mathrm{W}_{\min } / \mathrm{L}^{\prime} ; \mathrm{W}_{\max }=$ maximum width, $\mathrm{W}_{\min }=$ minimum width, and $\mathrm{L}^{\prime}=$ the longitudinal distance between the minimum width and maximum width.

Thin sections were cut from rock samples perpendicular to bedding. Rock samples were rinsed with ethanol to remove any potential organic contamination and then demineralized by $\mathrm{HF} / \mathrm{HCl}$ acid maceration to extract organic fossils. Laser microRaman spectra of the organic fragments with cellular structures and macrofossils in the host rock were collected on a Horiba-Jobin Labram 800 HR Raman spectrometer with an Olympus BX41 petrographic microscope at the Centre for Geobiology (CGB), University of Bergen, Norway, and a Horiba Xplora One Raman spectrometer with an Olympus BX41 petrographic microscope at the Guangzhou Institute of Geochemistry (GIG), Chinese Academy of Sciences. All analyses were made through a $100 \times$ objective, using $514 \mathrm{~nm}$ (CGB) and $532 \mathrm{~nm}$ (GIG) excitation of an Ar-ion laser adjusted to an absolute laser power of $15-20 \mathrm{~mW}$, translating (with the use of a density filter) to an on-sample intensity of ca. $2.5 \mathrm{~mW}$ (CGB) and $1.67 \mathrm{~mW}$ (GIG). Raman spectra acquisitions were performed in 'multi-window' mode with $2 \times 10$ (CGB) and $3 \times 12$ (GIG) seconds running time and a spectral range of $150-2,000 \mathrm{~cm}^{-1}$, and treated with software 'Lab Spec version 5.58.25'.

\section{References}

1. Narbonne, G. M. The Ediacara biota: Neoproterozoic origin of animals and their ecosystems. Annu. Rev. Earth Planet. Sci. 33, 421-442 (2005).

2. Xiao, S., Yuan, X., Steiner, M. \& Knoll, A. H. Macroscopic carbonaceous compressions in a terminal Proterozoic shale: a systematic reassessment of the Miaohe biota, South China. J. Paleontol. 76, 347-376 (2002).

3. Yuan, X., Chen, Z., Xiao, S., Zhou, C. \& Hua, H. An early Ediacaran assemblage of macroscopic and morphologically differentiated eukaryotes. Nature 470, 390-393 (2011).

4. Butterfield, N. J. The Neoproterozoic. Curr. Biol. 25, R859-R863 (2015).

5. Ye, Q. et al. The survival of benthic macroscopic phototrophs on a Neoproterozoic snowball Earth. Geology 43, 507-510 (2015).

6. Butterfield, N. J. Animals and the invention of the Phanerozoic Earth system. Trends Ecol. Evol. 25, 81-87 (2011)

7. Walter, M. R., Oehler, J. H. \& Oehler, D. Z. Megascopic algae 1,300 million years old from the Belt Supergroup, Montana: a reinterpretation of Walcott's Helminthichnites. J. Paleontol. 50, 872-881 (1976).

8. Sharma, M. \& Shukla, Y. Taxonomy and affinity of early Mesoproterozoic megascopic helically coiled and related fossils from the Rohtas Formation, the Vindhyan Suppergroup, India. Precambrian Res. 173, 105-122 (2009).

9. Grey, K. \& Williams, I. R. Problematic bedding-plane markings from the Middle Proterozoic Manganese Subgroup, Bangemall Basin, Western Australia. Precambrian Res. 46, 307-327 (1990).

10. Retallack, G. J., Dunn, K. L. \& Saxby, J. Problematic Mesoproterozoic fossil Horodyskia from Glacier National Park, Montana, USA. Precambrian Res. 226, 125-142 (2013).

11. Hofmann, H. J. in Paleoalgology: Contemporary Research and Applications (eds Toomey, D. F. \& Nitecki, M. H.) 20-33 (Springer-Verlag, Berlin, 1985).

12. Srivastava, P. Problematic fossils from the Palaeo-Neoproterozoic Vindhyan Supergroup, India. Arab. J. Geosci. 5, 1411-141622 (2012).

13. Knoll, A. H., Javaux, E. J., Hewitt, D. \& Cohen, P. Eukaryotic organisms in Proterozoic oceans. Phil. Trans. R. Soc. B 361, 1023-1038 (2006).

14. Javaux, E. J. in Origins and Evolution of Life: An Astrobiology Perspective (eds Gargaud, M., Lopez-Garcia, P. \& Martin, H.) 414-449 (Cambridge University Press, 2011)

15. Zhu, S. \& Chen, H. Megascopic multicellular organisms from the 1700millioan-year-old Tuanshanzi Formation in the Jixian area, North China. Science 270, 620-622 (1995)

16. Zhu, S. et al. Discovery of carbonaceous compressions and their multicellular tissues from the Changzhougou Formation (1,800 Ma) in the Yanshan Range, North China. Chin. Sci. Bull. 45, 841-846 (2000).

17. Lamb, D. M., Awramik, S. M., Chapman, D. J. \& Zhu, S. Evidence for eukaryotic diversification in the $\sim 1,800$ million-year-old Changzhougou Formation, North China. Precambrian Res. 173, 93-104 (2009).

18. Lamb, D. M., Awramik, S. M. \& Zhu, S. Paleoproterozoic compression-like structures from the Changzhougou Formation China: eukaryotes or clasts? Precambrian Res. 154, 236-247 (2007)
19. El Albani, E. et al. Large colonial organisms with coordinated growth in oxygenated environments $2.1 \mathrm{Gyr}$ ago. Nature 466, 100-104 (2010).

20. Knoll, A. H. The multiple origins of complex multicellularity. Annu. Rev. Earth Planet. Sci. 39, 217-239 (2011).

21. Zhang, S. H., Zhao, Y., Ye, H., Hu, J. M. \& Wu, F. New constraints on ages of the Chuanlinggou and Tuanshanzi formations of the Changcheng System in the Yan-Liao area in the northern North China Craton. Acta Petrol. Sin. 29, 2481-2490 (2013).

22. Meng, Q.-R., Wei, H.-H., Qi, Y.-Q. \& Ma, S.-X. Stratigraphic and sedimentary records of the rift to drift evolution of the northern North China craton at the Paleo- to Mesoproterozoic transition. Gondwana Res. 20, 205-218 (2011).

23. Wang, C. Biomarker evidence for eukaryote algae flourishing in a Mesoproterozoic $(1.6 \sim 1.5 \mathrm{Gyr})$ stratified sea on the North China Craton. Geoch. Cosmo. Acta 73, A1407 (2009).

24. $\mathrm{Lu}, \mathrm{S}$. N. \& $\mathrm{Li}, \mathrm{H}$. M. A precise U-Pb single zircon age determination for the volcanics of Dahongyu Formation, Changcheng System in Jixian. Bull. Chin. Acad. Geol. Sci. 22, 137-145 (1991).

25. Li, H. K. et al. Zircon U-Pb dating on tuff bed from Gaoyuzhuang Formation in Yanqiang, Beijing: further constraints on the new subdivision of the Mesoproterozoic stratigraphy in the northern North China Craton. Acta Petrol. Sin. 26, 2131-2140 (2010).

26. Pang, K. et al. The nature and origin of nucleus-like intracellular inclusions in Paleoproterozoic eukaryote microfossils. Geobiology 11, 499-510 (2013).

27. Javaux, E. J., Knoll, A. H. \& Walter, M. R. TEM evidence for eukaryotic diversity in mid-Proterozoic oceans. Geobiology 2, 121-132 (2004).

28. Yin, L., Yuan, X., Meng, F. \& Hu, J. Protists of the Upper Mesoproterozoic Ruyang Group in Shanxi Province, China. Precambrian Res. 141, 49-66 (2005).

29. Bell, G. \& Mooers, A. O. Size and complexity among multicellular organisms. Bio. J Linnean Soc. 60, 345-363 (1997).

30. Butterfield, N. J. Modes of pre-Ediacaran multicellularity. Precambrian Res. 173, 201-211 (2009).

31. Yoon, H. S., Hackett, J. D., Ciniglia, C., Pinto, G. \& Bhattacharya, D. A molecular timeline for the origin of photosynthetic eukaryotes. Mol. Biol. Evol. 21, 809-818 (2002).

32. Parfrey, L. W., Lahr, D. J. G., Knoll, A. H. \& Katz, L. A. Estimating the timing of early eukaryotic diversification with multigene molecular clocks. Proc. Natl Acad. Sci. USA 108, 13624-13629 (2011).

33. Eme, L., Sharpe, S. C., Brown, M. W. \& Roger, A. J. On the age of eukaryotes: Evaluating evidence from fossils and molecular clocks. Cold Spring Harb. Persp. Biol. 6 doi: 10.1101/cshperspect.a016139 (2014).

34. Douzery, E. J. P., Snell, E. A., Bapteste, E., Delsuc, F. \& Philippe, H. The timing of eukaryotic evolution: Does a relaxed molecular clock reconcile proteins and fossils? Proc. Natl Acad. Sci. USA 101, 15386-15391 (2004).

35. Berney, C. \& Pawlowski, J. A molecular time-scale for eukaryote evolution recalibrated with the continuous microfossil record. Proc. R. Soc. B 273, 1867-1872 (2006).

36. Shih, P. M. \& Matzke, N. J. Primary endosymbiosis events date to the later Proterozoic with cross-calibrated phylogenetic dating of duplicated ATPase proteins. Proc. Natl Acad. Sci. USA 110, 12355-12360 (2013).

37. Brasier, M. \& Lindsay, J. F. A billion years of environmental stability and the emergence of eukaryotes: New data from northern Australia. Geology 26, 555558 (1998).

38. Cawood, P. A. \& Hawkesworth, C. J. Earth's middle age. Geology 42, 503-506 (2014).

\section{Acknowledgements}

This project was supported by the National Natural Science Foundation of China (41272015), the Ministry of Science and Technology of China (2013CB835000), and the China Geological Survey (200313000052). A.H.K. thanks the NASA Astrobiology Institute for support. We thank X. Huang, L. Sun and Y. He for their assistance during field work, and L. Bian and Y. Xu for their cordial assistance in the laboratory.

\section{Author contributions}

M.Z. and S.Z. designed the research; S.Z. and S.S. discovered the macrofossils; S.Z., M.Z Z.Y., F.Z. and A.H.K. performed research; M.Z. and A.H.K. wrote the paper; Z.Y. and Y.Q. performed the Raman analyses. All authors joined discussions for the final draft of the manuscript.

\section{Additional information}

Supplementary Information accompanies this paper at http://www.nature.com/ naturecommunications

Competing financial interests: The authors declare no competing financial interests 
Reprints and permission information is available online at http://npg.nature.com/ reprintsandpermissions/

How to cite this article: Zhu, S. et al. Decimetre-scale multicellular eukaryotes from the 1.56-billion-year-old Gaoyuzhuang Formation in North China. Nat. Commun. 7:11500 doi: $10.1038 /$ ncomms11500 (2016). (c) (i) This work is licensed under a Creative Commons Attribution 4.0 International License. The images or other third party material in this article are included in the article's Creative Commons license, unless indicated otherwise in the credit line; if the material is not included under the Creative Commons license, users will need to obtain permission from the license holder to reproduce the material. To view a copy of this license, visit http://creativecommons.org/licenses/by/4.0/ 